\title{
WHAT IS AN E-TEXTBOOK?
}

\author{
Blaž Zmazek, PhD \\ Faculty of Natural Sciences and Mathematics \\ University of Maribor (Slovenia) \\ blaz.zmazek@uni-mb.si \\ Alenka Lipovec, PhD \\ Faculty of Education \\ University of Maribor (Slovenia) \\ alenka.lipovec@uni-mb-si \\ Igor Pesek, PhD \\ Faculty of Natural Sciences and Mathematics \\ University of Maribor (Slovenia) \\ igor.pesek@uni-mb-si \\ Vesna Zmazek, BA \\ High School Ptuj \\ vesna.zmazek@guest.arnes.si
}

Stanislav Šenveter, BA

High School Ptuj (Slovenia) stanislav.senveter@gmail.com

Jernej Regvat

High School Ptuj (Slovenia) jernej.regvat@gmail.com

Katja Prnaver, $B A$

Faculty of Natural Sciences and Mathematics

University of Maribor (Slovenia)

katja.prnaver@uni-mb.si

\section{Abstract}

The term e-textbook has not been defined either in Slovenia or elsewhere so far. This document presents the definition of basic characteristics of the content, didactical, technically useful and organizational aspect of an e-textbook creation, mostly based on experiences and good practice. Literature and other digital media mostly refer to e-textbook as a textbook in the form of an e-book, which is defined as a digital equivalent to the printed version. Most e-books and textbooks in digital form only take the advantage of digital media in portability and digital recording. 
Audio and video recordings are included in a small range of existing e-books, as the addition of quality and content appropriate sound and video to written context requires high level of technical and didactical knowledge. Priceless and for etextbook the most characteristic added value are for sure the interactive elements.

Key words: ICT, e-textbook, minimal requirements, interactivity

\section{Basic structure of an e-textbook}

Based on the basic characteristics of an e-textbook (Aberšek et al., 2010; Medveš et al., 2010), it contains a learning kit composed of following elements: textbook (for acquisition of new knowledge), workbook (for repetition and examination of knowledge) and learning tool (for practicing).

In the textbook, the content is presented with audio-visual and interactive elements which enable impressive acquisition of knowledge. It is recommended that each unit contain a summary, which allows the user to repeat the acquired knowledge with its integrated content, the content is split into content sections and is accessible in a menu tree (e.g. www.yteach.com, www.kii2.ntf.uni-lj.si/e-kemija/ mod/resourcel, www.e-um.si, ...); it covers the current curriculum, basic elements (materials) present closed learning units, combined in chapters and content sections, each web page (screen image) includes closed activity, acquisition or repetition of knowledge without the need to navigate between other web pages and may contain either full or partial content (web pages with split content are recommended in case of activities that are executed dynamically and sequentially in a limited area of a web page - e.g. www.yteach.com), the content is freely accessible without the required registration, the content can be simply modified and adjusted.

It is also important to define the levels of interactivity (Repolusk, 2009). The definition classifies playback of sound and video in an e-textbook as low-level interactivity. At the middle level of interactivity the user is given feedback, which depends on one's answer, while the high-level interactivity is defined as multiple interactions between the user and the system. There is no need to stress that elements with high level of interactivity allow high quality didactic tool in learning and teaching (Kolenc-Kolnik, 2007). Such elements are various didactical applets and games, as well as some exercises with randomly generated data and feedback on the solution.

The elements of a workbook are sets with a larger number of exercises (preferably with generated data) i.e. http://am.fmf.uni-lj.si, www.e-va.si, www.eum.si. Exercises are used to examine the knowledge and possibly consolidate it further, while tests (again, with generated data if possible) additionaly allow the evaluation of knowledge. A group of learning tools consists of activities in the form of didactic applets and games as well as accompanying documents (e.g. description of didactic approaches and aspects of individual elements of an e-textbook...).

The described structure of an e-textbook is intended for the general use in teaching and learning both at school and at home. The users are therefore pupils, 
students, teachers and parents. Clear structure and simple content accessibility is enabled with a curriculum-based menu structure.

\section{E-textbook axiomatic}

In the preparation stage of an e-textbook and confirmation of its suitability, the following basic axioms define content-didactical requirements (Hvala, Kobal and Zmazek, 2007; E-um team, 2009).

Axiom of curriculum coverage. Textbook must provide the student with an overview of complete knowledge, competences and skills that should be acquired in the subject. Textbook assures acquisition of expected standards which set the conditions to advance into next year.

Axiom of interactivity. Interactivity is the basic goal of a modern textbook. Authors should aim towards higher levels of interactivity, i.e. multiple loops in communication with the student.

Axiom of multimedia. Rather than pure text, a textbook should contain text in combination with appropriate and content related nonverbal elements. Students should be given large amounts of information and knowledge with visual content. Nonverbal elements should be in complement or symmetric function, whereas irrelevant nonverbal elements only present as a colourful, design effect, should be avoided as they can cause a loss of concentration.

Axiom of inductive approach. Deductive approach converts basic knowledge into individual examples. Inductive approach oppositely stems from individual examples and problems of concrete professional practice and includes the explanation (acquisition) of general theoretical principles in their solutions. Formulation of results always begins after the terms and results are intuitively absorbed.

Axiom of "fille rouge". E-textbook should attract the attention of the student and keep him/her motivated from the beginning until the end. Chapters should begin with the introduction explaining the idea of acquiring knowledge from a practical perspective and/or reaching the required level of knowledge for further study of the theory. The main part of the chapter should be clear, the content which is not basic should be hidden (e.g. under the button). The chapter should end with a summary that draws special attention to difficult and important matters, provides the definitions of basic terms, directs the user onto the links with previous, but even more important to future chapters. Questions should also be an essential part of the summary, as well as exercises and other elements, used for individual evaluation of knowledge in various forms, types and levels of difficulty. It is desired to have the data in the exercises generated.

Axiom of deepening. E-textbook should create an environment for in-depth experience, for example through experimenting with interactive applets. The part of the content that requires understanding should be larger than the part with exercises and lower taxonomic levels. Interactively designed e-textbook must demand from 
the student to solve problems with approaches that allow the development of general and generic competencies.

Axiom of unique outlook. E-textbook should maintain unique philosophy and form (e.g. unique design of titles, summaries, definitions, important goals, audio and video elements, additional content...).

Axiom of methodic didactic and lanuage suitability. E-textbook must obey all didactic principles, especially the principle of systematization, clarity, use of knowledge, activity and individualization options. E-textbook should fulfill all the requirements of a printed textbook (professional criteria, criteria of matching content with the curriculum, criteria of suitable methodical-didactical design, criteria of developmental-psychological suitability and criteria of language suitability).

\section{Minimal requirements for e-textbook}

A good e-textbook must in the first place sufficiently follow contentdidactical recommendations: professional suitability and apropriateness, curriculum coverage, it must contain multimedia elements, inductive approach, continuously guided individual content from the beginning until the end, environment for in-depth experience, unique cover design and operational view, correspond to the users' age group as well as methodic, didactical and language relevance.

Basic technical-operational requirements for a quality e-textbook are: open source authoring tools, free accessibility and flexibility of individual materials, smooth operation in most commonly used browsers, content must be compatible with SCORM 1.2 standard or higher, with individual SCORM packages for content sections or smaller units, minimum display resolution is 1024 x 768 pixels, automatic resizing of content to the display resolution, table of contents must be visible at any time, clear and easily accessible and must rely on the content distribution in content sections. Quality of audio-video elements is defined for bitmaps with minimal size of the bitmap (photo, illustration, graphs...) at least $640 \times 480$ px (at $72 \mathrm{dpi}$ ); the quality of bitmap must not be smaller than the basic resolution (the image has to be without squares and readable texts, if they are relevant). The quality of video is defined by the video player; it must be integrated in the content and be independent from the operating system or browser; the player must have unique graphical interface (control bar with buttons for navigation through the video - play, stop, skip,...) throughout the e-textbook; minimum size of the video is $320 \times 240 \mathrm{px}$ at compression rate $850 \mathrm{~kb} / \mathrm{s}$; video quality (sound, picture, tone) must not distract the message of the video content. The quality of sound is defined by: bit rate of the sound must be at least $96 \mathrm{~kb} / \mathrm{s}$; the sound must be clear (reader, speech) and uniquely designed through the e-textbook.

Basic element (material) presenting a completed learning unit should on average contain at least 2 interactive middle level elements related to e-material content, one multimedia element (sound, bitmap, video, animations,...) related to the content of e-material, with total length of at least 10 seconds, up to 2000 characters with spaces (less in lower grades) and can be, in case that some parts of 
the content are not related (no need to pass through them), designed as a collection of single pages, fitting on the display.

\section{Creating an e-textbook}

The creation of e-textbooks requires more sources, due to theirs complex technical and didactical implementation. Therefore the creation differs significantly from the creation of a printed textbook. The decision for an e-textbook mainly appears on the publishers' site, who order the chosen author to prepara the content and scenarios, while in printed textbooks, the publisher chooses between several written manuscripts. And this is why creation of e-textbooks requires extra attention to choice and training of authors, preparation of detailed axiomatic and e-textbook examples, definition of organizational structure and responsibilities of the team members, choice and modifications of tools for creating e-textbooks, definition of work schedule, production and definition of a review system and publishing and monitoring of use.

When developing e-textbook the technical aspect plays one of the key roles. This includes authoring tools for the development of e-textbooks, portal for continuous tracking of e-textbook elements (reviews...) and portal for display of etextbooks. Authoring tools enable authors to create elements, which are usually present in printed textbooks (text, image), as well as to create elements that take the advantages of electronic media (sound, video, interactivity).

We aim to choose authoring tools that are simple to use and at the same time effective, as we want to offer "scisors and panel" to authors, so they are able to express their creativity when creating e-material (Lipovec, Kobal and Repolusk, 2007). Authoring tools should be chosen in the planning phase as some time has to be assigned for the education of authors on the use of the tools.

\section{Open source authoring tools}

Experiences have shown that open-source authoring tools are the most suitable choice, as compared to commercial tools they have several advantages. First advantage is the price, since there are no software expenses for open-source tools. Another advantage is lively online communities, including programmers and authors of such tools. These communities are ready to help with advices and solutions, when a problem occurs in the development of e-materials, as many users intensively use the tools in other projects.

Another advantage is open access to the programming code of the authoring tool, which enables editing, and changing the code of the authoring tools, and later sharing the solution with the community. In the development of e-materials, subject specifics might require adaptation of the tool. For example, in mathematics, presentation of mathematical symbols can be such a problem. Most of authoring tools allow a limited range of special symbols that is usually not sufficient for the development of e-materials. If using open-source authoring tools, a solution can be 
usually found within the communities and implemented in own tools, whereas any forms of adaptation in commercial tools is usually restricted to the interest of the company and may not be done at all.

\section{Free accessibility and adaptation of e-materials}

Computers are developed faster each day. By looking at the e-materials developed few years ago, one might find some that are already considered not useful. As one often hits more advance users or project groups, which would like to or are ready to adapt existing materials to their needs and new options, it is required to make all the authoring tools freely available. Only such an approach will ensure that the e-materials can always be suitable in a technical sense.

It is important to note that there is no authoring tool for e-materials available on market, which would enable creation of all elements of some e-material within the same tool. Current solutions enable grouping of elements of different forms, design in specialized authoring tools, into a final e-material. Most known authoring tool is eXe that has been used by many Slovenian authors, while Articulate is the best known commercial product.

\section{Audio-video elements}

One of the previously mentioned forms, which are impossible to create in authoring tools for e-materials, are audio-video elements. They use the advantage of electronic media, as they can, if properly designed, increase the multimodality of ematerials. However, we need to be careful in the design of such elements - proper design requires lots of technical knowledge; quality is easily perceivable and can disturb the content of e-material if poor. When using these elements, one has to assure that they satisfy the minimal standards that are usually defined in the planning phase of e-materials. For the design of audio-video elements we use a wide range of specialized tools that exist in the market (e.g. audacity).

\section{Interactive elements}

Interactive elements are another type of elements, presenting the next level in the evolution of e-materials, as they enable interaction between the computer (ematerial) and user (student). Tools for creating interactive elements are usually very limited in a sense of interactivity type. This means that one can create one type of interactive elements with a tool. In general, the higher is the level of interactivity, more complex is the tool and development of the interactive element is more time consuming. Currently, there are several excellent tools available for the development of interactive elements, for example dynamic geometry tool Geogebra, quiz development tool HotPotatoes as well as tools for the development of dynamic exercises with generated data. 


\section{Presentation of e-textbooks}

The last phase of the development of e-textbooks is the presentation of materials on the World Wide Web. The most appropriate solution is collection of materials in online portals, which serves as a unique entry point to materials. The portal is available to everybody and does not require login or registration for use. The concept is modular, which means that new items (materials) as well as technical upgrades can be added in a simple manner.

Based on the accumulated good practices in producing e-learning materials are hereinafter in detail described procedures to ensure effective process of creating quality e-books.

\section{Organizational structure}

The creation of an e-textbook is a complex process that requires the highest degree of professional team of practitioners and experts of didactic (editorial team with external collaborators) and technicians (technical team). Skillful management of both teams is provided by people (management team) to whom subtle and systematic management of human resources and knowledge of quality management system is not strange. E-textbook is constantly changing and adapting, is a living organism. Its content is constantly evaluated and monitored by users and professionals. To maintain consistency and to continuously improve e-textbook through this maintenance, we need a solid background structure, which can provides coherence, consistency and quality. The following organizational structure is therefore essential.

Editorial team (from 3 up to 7 members) consisting of teachers and didactic practitioners, including university lecturers and a few experienced and competent high school or elementary school teachers who are experts in their field, are understanding, have a sense of quality, and know how to assess various areas and look into the possibilities offered by the media discussed. The editorial team is responsible for the substantive implementation of e-books (appropriate range of coauthors, reviews, organisation of calibration meetings, seminars, selection and placement of content and topics, the selection of contributions and material to form a comprehensive, uniform and appropriate high quality design and content of an etextbook. At least one member of the subject management team is also a member of the editorial team...).

Technical team is in charge of the preparation and maintenance of web portals, necessary for the smooth functioning of organizational and substantive core activities in the emergence of an e-textbook. The technical team is responsible for proper selection, coding, translation, adaptation and testing of the technical authoring tools. The team is composed of technology experts, software tools experts and programmers. Within the team, tasks are divided into development and implementation. The development section of the team is directly involved with the editorial team to forward the wishes, requirements and objectives of the editorial 
team to the group which decides on the selection of tools and software technical tasks of the team. Programmers and designers are people with discerning and innovative ideas who are able not only to realize, but sometimes also to upgrade ideas developed by the editorial and management team.

Management team is responsible for coordinated, time controled activities in the emergence of an e-textbook. They care for the proper distribution of human resources, their monitoring and communication between all teams listed. The management team collects opinions on important strategic decisions from the other teams and is responsible for implementing their strategies and decisions.

Prior to inviting foreign colleagues to develop e-learning materials in the process of an e-textbook creation, the editorial team must already prepare first copies of e-materials in place of content, instructional and technical standards for authors'materials. In the initial seminars, authors are presented axiomatics of ematerials through examples, created by the editorial team as well as in form of a document. For the preparation of samples of materials selection/coding of authoring tool is required beforehand. The features of tools and the simplicity of their use later largely impact the design and usability of an e-textbook. In the past, e-learning materials in Slovenia were mainly created according to the principle, where in the first stage, the author provides the text of the content and presents the ideas for the interactive elements of e-learning materials and advice on how to prepared them, while in the second phase the technical persons (computer experta), who are associated with the content only as copyists, develop these interactive elements. Therefore, many difficulties have arisen: the author, who conceived the idea of interactive elements and was very poorly (or even not at all) familiar with the tools to be used, did not realize what can and cannot be created. On the other hand, the technician who has been instructed what to create, tailored author's instructions in line with the technical capabilities and the product was often not methodologicaly sound. To avoid difficulties it is reasonable to find or create a tool that allows, after a short education, to be used by average skilled technical writers.

External contributors - authors of e-learning materials are teachers who meet the tender specifications for authors, and provide the necessary supporting documents. These are usually renowned experts - practitioners who have distinguished themselves with their work with particularly notable products, participated in training and meetings of subject and study groups; produced exceptional training materials, presented their results at conferences and professional meetings and similar. External collaborators (writers) are invited to also provide a sufficiently broad regional spread in addition to a sufficiently large circle of highquality staff. This plays a big role in the subsequent promotions of an e-textbook among teachers. Initial seminar should be organized for all interested authors, where the participants get acquainted with the tools and organization of work. After the seminar the participants produce a few e-learning materials in a short priod (up to 14 days) and deliver it to the editorial team for assessment and evaluation of the authors and choice of authors. Short period is in some way an exclusionary factor for those participants of the seminar who have difficulties adapting to short deadlines in further work. It should be particularly noted that in the choice of authors attention 
has to be paid to all three competencies (conceptual, educational and technical), as a very good technically knowledgeable teacher without teaching ideas does not promise a quality product in terms of an e-textbook. Under the supervision of editors, the chosen colleagues are introduced into work. Each of their material should be reviewed three times in the process of publication (expert, chief editor and teacher practitioner), and pass a grammar review. In the first stage of the preparation of their e-material, calibration meetings are organised to highlight the good and bad materials, exchange didactical and technical ideas and tune the authors with the editorial and technical team into a good-sounding orchestra, which will ultimately ensure that the e-textbook will have a unique recognizable shape, in terms of content, and to ensure user-friendly thread in didactical aspect. Selection, validation and verification of employees / co-authors are done by the editorial team.

Calibration meetings. In order to achieve adequate quality of an e-textbook, it is necessary to organize a calibration meeting - additional training and motivation, rich exchange of ideas and the implementation of specific topics. There should be two or three meetings shortly after the start and then at least one more during the project period. This is an opportunity to directly compare the useful achievements and see good and poor individual products, create conditions for reaching the target, which is context and uniqueness in the design of an e-textbook, and completely meet the goals as well as technical and media requirements.

When the e-textbook is finally published, a small group is formed from the above teams, that caters all comments, identified errors and weaknesses with the aim of a continuous improvement.

\section{Implementation plan}

When making an e-textbook, it is necessary to follow the implementation plan and a preliminarly detailed timetable for phased construction of an e-textbook. E-textbook consists of a large number of e-learning materials to be reviewed by at least two (preferably three) reviewers and editors. The authors, reviewers and editors should have clear time limits set within which they must do their work, as in a great number of e-learning materials and larger number of authors, reviewers, editors and proofreaders, the coordination of construction of an e-textbook is very difficult, as well as the implementation of the timetable.

It is recommended that real-time automated accompaniment of all activities is conducted through the administrative portal, which enables transparent tracking of the progress of construction of e-textbooks in the following formats: Calendar - an overview of all meetings, working meetings and other future deadlines determined by the schedule. Activities - an overview of tasks and monitoring of staff assignments until realization. Timeline - continuous reporting on the work. Reviews - online reviews of e-materials and automated production of peer review document. Statistics - the total statistics on all aspects of monitoring (monitoring of authors, monitoring the percentage of produced e-materials, monitoring the percentage of peer-reviews and proofreading of e-materials...). 


\section{The automated review system}

To ensure adequate quality and quality of materials, any material must be thoroughly examined before publishing by at least two, preferably three reviewers. The (main) reviewer must thoroughly review the material in the context of the provided objectives and requirements for e-learning materials. He or she must pay attention to all the details. As the entry point of the review cycle, the reviewer is directly related to the author of the material and has the option of refusing the material before it properly enters the review cycle. The editor has a larger number of materials to review, and thus a better overview of the coverage of topics and positioning in the structure. Editor's comments relate to the material mainly in connection with the positioning among other materials and the e-textbook as a whole. The practitioner has the task of verifying the correctness of the material, especially from a practical point of view. This includes the correctness of the examples and other recorded interpretations of the facts. The practioner may also make comments about the content.

To facilitate the control and management of peer review documents, an electronically supported application must be available to the authors and all reviewers, which allows for: creation of peer review documents, overview of duties and review of the state of e-materials. At the same time such an application allows the administrator to set up the reviewers and the management of peer review cycle. All the reviews must be written in the review document. This document is an official document of communication between the reviewers and the authors of materials. Within the review cycle, a working review document circulates among the reviewers for each version of the e-material, which is transformed into the final document before being forwarded to the author. For each version of the material sent by the author, the review cycle begins with the reviewer who opens a new working review document. The form of a review document is optional; however it is advisable to include fields to enter free text, as well as a selection of questions where the reviewer evaluates the answer to each question. Each reviewer writes general comments in the text boxes, but should also be able to comment on specific details in the text. This can be achieved either by numbering the lines in the e-material or by interactive inserting of comments in the material. Text boxes should have some editing options enabled in the text fields, such as the use of bold or italic font, font size, etc... After completing the review each reviewer should be allowed to confirm the material and thus forward it to the next link in the review cycle or conditionally accept the material and pass it on in the cycle, but at the same request for it to be reviewed again or reject the material, which interrupts the review cycle. Since it is a working document, which involves more reviewers, the comments, evaluation grades and other records of each reviewer must be reasonably marked, either in colour or by inserting any other indication.

When the review cycle is completed (by termination or the comment of the practitioner) it is necessary to create a final review document. This is done by the first reviewer. He or she can keep all the comments of the reviewers or summarize 
them in a meaningful whole. If all the reviewers of the e-material confirm the material in the review cycle, the review process is complete and the material is suitable for a grammar review; if not, the e-material si returned to the author, who must modify the material according to the comments.

Each version of the material and each pertaining review document should be accessible at all times. This allows a better overview of the material through the review cycles, while enabling the reviewers observation of the changes between the old and the new version of the material. If possible, the differences between the versions should be visible. The system should allow the administrator and other authorized users to know at any moment the present stage of the review cycle, and a review of the number of rounds should be allowed. Temporal information on the review process in the cycle allows control and identification of "bottlenecks" and makes it easier to ensure proper peer review process. Even after the completion of peer review cycle, it should be possible to make changes. The administrator should be able to re-engage each material into the review circuit (with a comment as to why it is being reviewed again) or determine reloading of material without further review.

Once the materials are effectively reviewed and edited, they are suitable for publication. Inspite of a thorough review, it is possible for mistakes to occur or subsequently identified missing elements are discovered; therefore it must be possible for users of e-textbook materials to send comments to the editors. The user should also have the option to leave e-mail for any questions related to the comment. The person responsible for reviewing comments must periodically monitor user comments. Special attention should be paid to selection of comments reporting any faults and they should be checked. If necessary, he or she should notify the administrator to arrange for a calibration of the material.

\section{Bibliography}

Aberšek, B., Kordigel Aberšek, M., Ivanuš Grmek, M., Škapin, D., Gerlič, I. and Krašna, M., (2010). Vrednotenje e-gradiv. Poročilo o izvajanju modula Vrednotenje e-gradiv znotraj projekta Izobraževanje izobraževalcev Ro.

E-um team (2009). Aksiomatika e-gradiv, interno gradivo.

Hvala, B., Kobal, D, in Zmazek, B. (2007). Vsebinska zasnova in iz nje izhajajoča aksiomatika E-um gradiv In: VREČA, Maja (Ed.) \& Bothe, Urška (Ed.). Mednarodna konferenca Splet izobraževanja in raziskovanja z IKT, SIRIKT 2007, Kranjska Gora, 19. - 21. april 2007. Zbornik. Ljubljana: Arnes, 2007, str. 250-254.

Lipovec, A., Kobal, D. in Repolusk, S. (2007). Načela didaktike in zdrava pamet pri eučenju. In: Vreča, Maja (Ed.) \& Bothe, Urška (Ed.). Mednarodna konferenca Splet izobraževanja in raziskovanja z IKT, SIRIKT 2007, Kranjska Gora, 19. - 21. april 2007. Zbornik. Ljubljana: Arnes, 2007, str. 119-223.

Kolenc-Kolnik, K. (2007). Mnenje o izobraževalni vrednosti spletnega e-učnega gradiva, Filozofska fakulteta Maribor. 
Medveš, Z. et al, (2010). Splošna posebna didaktična izhodišča ter tehnična izhodišča za pripravo e-gradiv, Ljubljana: Impletum.

Repolusk, S. (2009). E-učna gradiva pri pouku matematike. Magistrsko delo, Fakulteta za naravoslovje in matematiko, Univerza v Mariboru.

\author{
Metodički obzori 7(2012)2 \\ Pregledni rad \\ UDK: 371.671:004 \\ Primljeno: 15. 10. 2010.
}

\title{
KAJ JE E-UČBENIK?
}

Blaž Zmazek, PhD

Fakulteta za naravoslovje in matematiko

Univerza v Mariboru (Slovenija)

e-mail: blaz.zmazek@uni-mb.si

Alenka Lipovec, PhD

Pedagoška fakulteta

Univerza v Mariboru (Slovenija)

e-mail: alenka.lipovec@uni-mb-si

Igor Pesek, PhD

Fakulteta za naravoslovje in matematiko

Univerza v Mariboru (Slovenija)

e-mail: igor.pesek@uni-mb-si

Vesna Zmazek, BA

Gimnazija Ptuj (Slovenija)

e-mail: vesna.zmazek@guest.arnes.si

Stanislav Šenveter, $B A$

Gimnazija Ptuj (Slovenija)

stanislav.senveter@gmail.com

Jernej Regvat

Gimnazija Ptuj (Slovenija)

e-mail: jernej.regvat@gmail.com

Katja Prnaver, BA

Fakulteta za naravoslovje in matematiko

Univerza v Mariboru (Slovenija)

e-mail: katja.prnaver@uni-mb.si

\section{Povzetek}

Pojem e-učbenika pri nas in v svetu do sedaj še ni bil formalno definiran. Pričujoči dokument predstavlja opredelitev temeljnih značilnosti vsebinsko didaktičnega, tehnično uporabniškega in organizacijsko izvedbenega vidika priprave e-učbenika, predvsem na podlagi izkušenj in dobre prakse. V literaturi in digitalnih medijih se pojem e-učbenika (e-textbook) uporablja za učbenik v obliki 
e-knjige (e-book), ki je definirana kot elektronski (digitalni) ekvivalent tiskani verziji (e-knjige lahko predstavljajo tudi online/spletni časopisi in digitalne knjige v obliki avdio knjig). Večina e-knjig in učbenikov v e-obliki prednost digitalnega medija izkorišča le v smislu prenosljivosti in digitalnega zapisa. Mnogo oblik učbenika v digitalni obliki ima v aplikaciji dodane funkcionalnosti programov za interaktivne table (označevanje, dopisovanje, pripenjanje slik in dokumentov,...) kot pomoč uporabnikom. Zvočni in video zapisi so vključeni v le majhnem deležu obstoječih e-knjig, saj zahteva dodajanje kvalitetnega in vsebini primernega zvoka in videa $\mathrm{k}$ tekstovnemu zapisu veliko tehničnega in didaktičnega znanja. Neprecenljivo in za e-učbenik najbolj karakteristično dodatno vrednost gotovo predstavljajo interaktivni elementi.

Ključne besede: IKT, e-učbenik, minimalne zahteve, interaktivnost. 